\title{
Understanding social innovation in services industries
}

\author{
Faiz Gallouj, Luis Rubalcaba, Marja Toivonen and Paul Windrum ${ }^{(*)}$
}

\begin{abstract}
This paper puts forward a framework for understanding the relationship between service industries and social innovation. These are two, previously disconnected research areas. The paper explores ways in which innovation in services is increasingly becoming one of social innovation (in terms of social goals, social means, social roles and multi-agent provision) and how social innovation can be understood from a service innovation perspective. A taxonomy is proposed based on the mix between innovation nature and the locus of co-production. The paper additionally puts forward a theoretical framework for understanding social innovation in services, where the co-creation of innovation is the result of an interaction of competences and preferences of multiple providers, users/citizens, and policy makers. This provides the basis for a discussion of key avenues for future research in theory, measurement, organisation, appropriation, performance measurement, and public policy.
\end{abstract}

\section{Key words:}

Services, innovation, social innovation, multi-agent framework

(*) Author order is alphabetical. Faiz Gallouj is at the University of Lille, Luis Rubalcaba is at the university of Alcalá, Marja Toivonen is at VTT and Paul Windrum is at the University of Nottingham. 


\section{Introduction}

Services face increasing social needs and challenges. An example is the design and delivery of health services in the conditions of ageing population and diminishing public resources. Another example is transport services which have to connect distant places in the era of globalization and simultaneously contribute to sustainability and a better quality of living in cities and local areas. Further, millions of poor people around the globe claim for satisfaction of their basic needs, which can be achieved via innovative and inclusive social and public services. In addition to innovative services, social innovations are part of the solution to answer the needs and meet the challenges. They also answer the growing demand of citizens to be actors in their own life and to find collective solutions to the social issues that they encounter.

While the involvement of citizens in innovation processes is not a new phenomenon, the modes and levels of engagement have drastically evolved over the last two decades. Theoretical models of social practice have also developed. Globalization and digitalization have had a major impact on society, allowing the collaboration of citizens, consumers, producers, innovators and investors. Possibilities to connect and act have increased, empowering individuals to participate more actively in various spheres of society.

Nowadays, a major part of innovation processes takes place services. From a sectorial point of view, societies in the XXI century are service societies, since services dominate the value added and employment. (In year 2015 the services sector counted about $69 \%$ of the value added in the world economy, and the share of services within agriculture and manufacturing - not visible in statistics - is continuously growing). This implies a remarkable change to the old view of the economists of the XVIII and XIX centuries (e.g. Adam Smith, 1776), who thought that services perform a certain useful role in society but add little or nothing to value creation. Services were regarded as non-productive, non-capital intensive, non-tradable and noninnovative; accordingly, innovation in services was not considered significant.

The myth about the non-innovative character of services was a core of economic thought until the mid-1990s (Gallouj, 2002). Today, this myth is losing its power along with the development of knowledge and technology, which have converted even traditional services into productive, innovative and tradable. The development is pronounced in knowledge-intensive business services (KIBS), which are not only highly innovative per se, but are also drivers of innovation and productivity for other economic sectors (Hipp, 1999; Miles, 2005; Strambach 2008; Tether, 2005). Also public and social services are areas in which innovation is possible and necessary (Albury, 2005; Windrum and Koch, 2008; Osborne and Brown, 2013; Djellal et al., 2013). Actually, the extensive literature on service innovation indicates that all kinds of services can nowadays be considered potentially innovative (Gallouj and Djellal, 2010; Djellal and Gallouj, 2012).

Social innovation is closely linked to service innovation and there is some overlapping between the two phenomena. The core of service consists of co-production and value co-creation as the interaction between a supplier and a user defines the service and the room for service innovation. Because co-production takes place in the societal context and is influenced by societal issues, social innovation meets service innovation. In recent years, there has also emerged an increasing interest in the extent to which service and service innovation can be regarded as a result of social innovation with social ends and social means. Thus, social 
innovation is often a service innovation but it is also, and increasingly, innovation in services. In the literature, there is growing understanding of how service innovation works in the private sector, on the one hand, and in public services, on the other hand. However, understanding on how service innovation works in the society in a wider sense - including the entire society with its institutions and the whole service system - is still a key topic for further research. Correspondingly, the multi-actor way of producing service innovations, i.e. the way in which different actors participate in co-production, is a underexplored topic.

These topics are relevant, not only from the perspective of service studies, but also from the perspective of innovation studies. Traditionally, innovation has been analysed mainly in terms of the creation and implementation of new or improved products and processes, driven by scientific knowledge and the related technology. Organisational innovations open up new ways to explore the forms of innovation in firms and organisations where personal and institutional interactions play a major role. Social innovation represents a further step in widening the view on innovation. It highlights that societies and citizens are not mere recipients of innovations, but they can be protagonists of innovations and co-innovators in some cases. In this sense, social innovation is also linked to system innovation.

This opening article for the special issue of Industry and Innovation analyses the key linkages between services and social innovation in more detail. It presents a theoretical framework for understanding social innovation in services and suggests main avenues for future research. A brief presentation of the selected papers and some concluding remarks are also included.

\section{Services and the definition of social innovation}

Unlike the substantial development achieved by service innovation literature (Djellal and Gallouj, 2012), social innovation is still an emerging field and the concept itself is fuzzy to some extent. There are several approaches and different disciplines contributing to the analyses (Pol and Ville, 2009; Van den Have and Rubalcaba, 2016). Sociologists, geographers, psychologists, and, to a lesser extent, economists, have all provided views and definitions. For example, the sociological view by Hochgerner (2013) defines social innovation as the "new combination of social practices". Here, the notion of "social change" is central (Howaldt and Schwarz, 2010). Economic geographers base their concept on social relations. In this spirit, Moulaert et al. (2013) pay attention "not just to particular actions but also to the mobilizationparticipation processes and to the outcome of actions which lead to the improvements in social relations, structures of governance, greater collective empowerment and so on". Pol and Ville (2009) represent an economic approach, focusing on "desirable social innovations based on the creation of new ideas displaying a positive impact on the quantity and/or quality of life". There are also economic approaches that do not focus on the definition but provide a framework. An example is Reinstaller (2013) who borrows the key concepts from institutional economics, evolutionary (game) theory and the capabilities approach to welfare economics.

It is interesting to notice that services do not have a prominent place in the definitions of social innovation. At the most, they are a category of social innovation, like in the EU report TEPSIE (2013). This fact reflects a more general situation: services play a minor or no role in the majority of social innovation literature. Exceptions are the analyses by Djellal and Gallouj (2012), Harrisson et al. (2010), Rubalcaba (2016), and Windrum et al. (2016), in which services 
are seen to be the core of social innovation. This is because new or improved services are often the outcomes of social innovation, as identified by OECD (2000): "Social innovators identify and deliver new services that improve the quality of life of individuals and communities, using innovative processes aiming for instance at new labour market integration, social inclusion, finding new ways to address health care, education delivery, resource efficiency and environmental challenges". In addition, the central role of user-provider interaction is a typical feature of both services and social innovation: co-production, which is a basic characteristics of services, is also found in social innovation. There are also differences between service innovation and social innovation. Specificities of social innovation are, among others, the nature of incentives that reflect social goals and the nature of empowerment that can be challenging due to the lack of readiness of citizens to engage in innovation.

These similarities and differences are included in the following definition that we have formulated based on a services perspective and on the previous literature highlighting this perspective. We suggest that social innovation consists of "new service solutions to societal challenges aiming to increase welfare by value co-creation and co-implementation through coproduction among multiple empowered actors". Our definition points out that services are a key ingredient in social innovation. However, this opening article also contributes to the understanding of the reverse influence: how services innovation develops into social innovation, i.e. how social innovation becomes an ingredient of service innovation.

\section{Services becoming more social, service innovation becoming social innovation}

Even though the social dimension has always been present in the services economy and in the service literature (Gershuny, 1978; Gershuny and Miles, 1983; Normann, 1984; Harrisson, 2010; Djellal and Gallouj, 2011), it has become more and more essential over time. There are multiple examples showing that services are nowadays social in a way that did not happen 20 years ago. One development trend is openness. Among the examples of open innovation in services (e.g., Chesbrough, 2011), many illustrate a wide participation of users in innovation processes. Even if the main goal is still business (not a social goal), companies like Amazon in distributive trades; Waze, Uber and Car2Go in transportation; and mobile banking and crowdfunding platforms in the financial sector are all cases of openness and user innovation. They foster value co-creation and aim to move to a more social level of co-production. However, most of them cannot be considered genuine social innovations, as they do not represent innovation with social goals, but business goals are their core.

Examples of services and service innovations which include both social ends and social means do also exist. The universities launching Massive Open Online Courses (MOOCs) free of charge are one example. They are very inclusive for poor people, and so is M-PESA mobile banking in the African financial sector; it allows transactions from remote places for people with weak or even totally missing transportation services (Mbiti and Weil, 2011). Another type of example on how service innovations become social is public-private innovation networks (Gallouj et al., 2013). They are not necessarily open and they are generally quite small and professional with rare engagement of end users, but they represent multi-agent co-production in which the third sector often plays an important role. Institutionalisation is also a way to foster the social nature of services. This is happening, for example, in education when the funding of charter schools is defined by their innovative character; in the health sector when new models of disease prevention require strong commitments from health bodies; and in tourism when innovation converting rural agriculture areas into touristic spots needs high coordination between regional and municipal bodies and local communities. 
What is new in all the reported examples is the growing range of social characteristics in service innovation. These characteristics can be summarised as follows:

a) More social ends (Pol and Ville, 2009; Bouchard, 1999). This is happening for two reasons. Firstly, there is a growing number of services with new types of social ingredients. The increasing activity of the third sector, which is globally observable, is strengthening the social nature of the service economy. In private companies, Corporate Social responsibility (CSR) has created sensitiveness about social issues, and provided incentives to companies to work in social projects. Social projects and business projects can also be interlinked, and social goals can be considered a mean to achieve business goals. Secondly, social aspects are today included in the traditional goals of many services. For example, the correct diagnosis and care in health services has been complemented by prevention, which requires new kinds of social actors and social skills. Correspondingly, transportation services do not include only mobility but environmental issues are also highlighted, which adds social goals to the traditional ones. In tourism, a repertoire of high quality services is not enough but a holistic service experience is emphasised, leading to an inclusion of social elements. In education, the focus is not only on the curriculum but teaching and learning social values are part of the goals (e.g., fighting against bullying and misbehaviours in social networks). Finally, public administration does not only aim to inform citizens through e-government platforms but uses digital platforms for the development of interactive practices and follows the principles of open governance.

b) More social means and inputs. Traditionally, innovation in goods has largely relied on $\mathrm{R} \& \mathrm{D}$ and human and physical capital. While the situation is changing in the material world, too, the research into service innovation has criticized this narrow view right from the beginning. It has shown that other inputs, such as the use of ICT and KIBS, are crucial in service innovations. The perspective of social innovation adds social communities as inputs to the innovation process. Co-production has moved from business-client and provider-user relationships to provider-society relationships, in which social networking is essential. Social (broad) co-production and individual empowerment are needed for the realization of value (Lallemand, 2001). Transformations of health care and agriculture provide illustrative examples. Innovation in health is not only based on $\mathrm{R} \& \mathrm{D}$, labs work and science, but social networks and participatory processes with patients play an important role and answer the need to utilize tacit knowledge besides explicit information. In social networks, the input of the third sector is continuously growing, both directly and indirectly. In the rural works, the transformation of an agricultural area into a touristic one is not possible without co-innovation and empowerment of the local communities.

c) More social roles in the service co-production. This element refers to the different roles played by actors in service/social innovation. The distinction between the provider and the user is blurring since users can become the providers of a technical solution (e.g., in the self-treatment for diseases). It is also possible that the users lead the innovation process (so-called user-led innovation), as often happens in the communities creating new or improved social services (for example, user-led organizations providing innovative services for addressing drug addiction). Correspondingly, the providers can play multirole, also acting as users. 
d) More social actors in multi-agent contexts. This point elaborates further the abovementioned transformations from the traditional bilateral relationships between the provider and the user into relationships in which multiple agents interact. The multiagent framework that we will discussed further in section 3 was originally developed for understanding service innovation (Gallouj and Weinstein, 1997; Windrum and Garcia Goñi, 2008), and it can be supplemented with the inclusion of social actors such as NGOs and other actors from the third sector. At a more detailed level, the possible actors are front-line workers, final users, professional associations, public or semipublic bodies, and community platforms - all of which add inputs to the traditional inputs of managers and designers in service innovation. The growing role of new actors in service innovation is one of its major characteristics (Rubalcaba et al, 2012). In the public sector innovation, the role of voluntary organisations is particularly relevant (Osborne, 2013)

To characterize and monitor the move from service innovation to social innovation, a taxonomy of service innovation types combined with types of organizations devoted to innovation is useful. We suggest a three-dimensional taxonomy. The first dimension concerns the goals and includes the service innovations mainly oriented to business and profit, on the one hand, and the service innovations mainly oriented to non-profit social ends, on the other. As the innovation can be more business- or more socially-oriented, i.e. there are many situations in between, we highlight the word "mainly" (instead of "purely" business or "purely" social). The second dimension is about the means and the level of co-production, building on the approach of user-based innovation in services (Sundbo and Toivonen, 2011). We propose three levels of user engagement: user-oriented, user-driven, and co-innovation (including user-led innovation). In the user-oriented situation, the provider is fully leading the innovation process but takes into account the needs of users (based on a survey, for example). In the user-driven situation, the users participate in the innovation process via formal engagement while in coinnovation, they are active participants. The beneficiary and user can be titled a customer, a client, or a citizen. The third dimension describes the locus of co-production. It can be the markets (companies and clients), public services and the government, community services, or a multi-agent and service system. Our "locus-based" categorization is not totally new in the service innovation literature: Osborne et al. (2016) have made a similar "locus-based" exercise to categorize public services; they ended up with four types of co-production for creation of value. Our categorization include both public and private services and to provide room for social innovation.

The role of social innovation in service innovation: taxonomy and some examples of key areas 


\begin{tabular}{|c|c|c|c|c|c|}
\hline \multirow{2}{*}{$\begin{array}{l}\text { Nature of } \\
\text { innovation }\end{array}$} & \multirow{2}{*}{$\begin{array}{c}\text { Co-production } \\
\text { level }\end{array}$} & \multicolumn{4}{|c|}{ Locus of service co-production } \\
\hline & & $\begin{array}{c}\text { Markets (companies \& } \\
\text { clients) }\end{array}$ & $\begin{array}{l}\text { Public services and } \\
\text { government }\end{array}$ & $\begin{array}{l}\text { Community services } \\
\text { (NGOs, third sector) }\end{array}$ & $\begin{array}{l}\text { Multiagent and service } \\
\text { system }\end{array}$ \\
\hline \multirow{3}{*}{$\begin{array}{l}\text { Mainly business- } \\
\text { ends oriented } \\
\text { innovation }\end{array}$} & User-oriented & * Basic service innovation &.- &.- & \multirow{3}{*}{$\begin{array}{l}\text { * System innovations } \\
\text { through public-private } \\
\text { business oriented networks }\end{array}$} \\
\hline & User-driven & $\begin{array}{l}\text { * Living labs based } \\
\text { innovations }\end{array}$ &.- &.- & \\
\hline & Co-innovation & $\begin{array}{l}\text { * Open innovation in } \\
\text { services }\end{array}$ &.- &.- & \\
\hline \multirow{3}{*}{$\begin{array}{l}\text { Mainly social-ends } \\
\text { oriented innovation }\end{array}$} & User-oriented & * Innovation in CSR & $\begin{array}{c}\text { * Digital transformation } \\
\text { and new public governance }\end{array}$ & $\begin{array}{l}\text { * Social } \\
\text { entrepreneurship }\end{array}$ & \\
\hline & User-driven & $\begin{array}{c}\text { * Workers and clients } \\
\text { engagement in CRS activities }\end{array}$ & $\begin{array}{l}\text { * Government living labs * } \\
\text { open public governance }\end{array}$ & $\begin{array}{c}\text { * Inclusive technological } \\
\text { innovations }\end{array}$ & \\
\hline & Co-innovation & $\begin{array}{l}\text { * Social innovation by } \\
\text { socials and means within } \\
\text { main business activities }\end{array}$ & $\begin{array}{l}\text { * Social innovation by } \\
\text { citizens engagement for } \\
\text { new public service design }\end{array}$ & $\begin{array}{l}\text { * Social innovation by } \\
\text { community } \\
\text { empowerment in third } \\
\text { sector service } \\
\text { innovations }\end{array}$ & $\begin{array}{l}\text { * System innovations } \\
\text { through public-private } \\
\text { social oriented networks }\end{array}$ \\
\hline
\end{tabular}

The examples within the taxonomy illustrate service innovations, some of which can also be considered social innovations that have resulted from the above-described transformations. Most service companies stay in the business area, adopting a more open approach to innovation. They may launch an open innovation initiative (like in the case of contests or innovation awards) or test new service products in living labs, for example. Usually there is some social content, but not enough to speak about "social innovation". Social goals in firms are often focused on topics of corporate social responsibility (CSR). The level of user engagement varies in CSR initiatives; in some of them, front-line workers and local communities are the recipients. There are also examples of genuine social innovations in private firms, i.e. the main business is transformed so that both the ends and means are social. For instance, an electricity company may launch a new product addressed to poor rural areas and local communities are actively engaged in the design of the electricity distribution. A hotel chain or transportation company may similarly focus on unfavourable areas and engaging processes; also microcredits in the financial sector are an example of this kind of business. Empowering and engagement often require investments and the approval and support from public authorities and local governments.

Even though examples of social innovations in private companies are increasing, the majority of social innovations emerge in public sector and third sector. In public services, the social end is present almost by definition. However, this is not enough to consider them social innovations because also social means are needed. Development to this direction starts when the public administration increases its openness towards citizens and users (adopting user-oriented innovation). For instance, digital tools can be used to promote new public governance, or the open public governance may develop user engagement platforms and living labs. This kind of user-based innovation becomes social innovation when there is an effective participation of citizens in the service design and delivery.

Social entrepreneurship and inclusive innovation ("technology for poor") are often presented as cases of social innovation because social goals play a central role in them. Even though inclusive innovation is clearly user-driven in that it is designed to satisfy needs of poor people, it is not social innovation unless there is a strong engagement of users. A good example is provided by the launch of new technologies for water purifiers in India, many of them being built in the US in top research centres. Those technologies are user-oriented and sometimes 
user-driven, since local communities have contributed to their design, but they include only limited engagement. Once the technology has been localized in India, social innovation is needed to organize local communities and actors to bring the purified water to the people, who often live far from the purifiers' locations. The technology by itself cannot solve this issue but a certain empowerment effort is needed.

The final category - the multi-agent and service system innovation - combines different types of actors from the private, public and third sectors. Here, illustrative examples are provided by public-private service innovation networks (ServPPINs). Some of them have mainly business goals and are not social innovations, while others pursue social goals and use social means. As mentioned earlier, a limiting factor is sometimes that they are not open to all potential actors and citizens and do not use social networks. For example, NGOs may represent the end users in the co-production of innovation. What is relevant is the dominance of social goals and ends, regardless of the variety of the depth and wideness of the openness and the use of social networks. The work by Gallouj et al. (2013) report examples on the two types of ServPPINs. 


\section{Theoretical framework for social innovation in services}

In this section of the article, we start by summarizing the key features of social innovation. Based on this summary, the main contribution of this section is the construction of a multiagent model of innovation. Following the results from previous sections, the first feature that distinguishes social innovation from other types of innovative activity is the intended 'ends' or 'goals'. These are firmly focused on improving social welfare, with an emphasis on innovations that address key societal (social and environmental) problems - e.g. ageing population and a declining workforce to support it, the increase of chronic diseases, global warming, and citizens' access to scarce resources (financial and other resources) particularly in developing countries. Where new goods and services have significant externalities, the social benefit of social innovation will be greater than the private benefit to the innovator.

The second main feature of social innovation is that it is also "social" in its process, not only in its outcome. Thus, an emphasis is placed on the new ways in which citizens are empowered in defining, developing, and implementing a social innovation. Lallemand (2001), among several other authors, highlights this as the defining aspect of social innovation - one which distinguishes it from more traditional, provider-driven innovation. Social innovations tend to be local, "bottom-up" solutions to social problems, with a variety of stakeholders involved.

Social innovation broadens the innovation concept to include social change produced by social action. Social innovations are mediated by/related to new or improved services that better meet social needs than pre-existing service solutions. Services are developed and selected within a complex, multi-agent environment. This environment includes local providers of services, policy makers, and heterogeneous groups of end users (citizens).

The multi-agent model presented here is based on Windrum and García-Goñi, (2008), Windrum (2013), and Windrum et al. (2016), and is rooted in the work of Kelvin Lancaster (1966) on product characteristics and consumer demand. Lancaster $(1966,1971)$ observed that products (both material goods and immaterial services) can be described as a bundle of 'service characteristics' (or attributes) that a good/service embodies (vector $\left[S_{1}, \ldots, S_{\mathrm{s}}\right]$ in Figure 1). Lancaster's insight is that consumers do not desire a product in itself but rather the particular bundle of service characteristics that it offers. A key aspect within the core set of service characteristics of a social innovation is the positive impact a service has on social welfare and the quality of life for a large number of citizens. For example, in community micro-financing and health insurance systems it is the extension of access and cover to (previously excluded) citizens that is a core characteristic of the service. 
Figure 1. Multi-agent framework (Windrum and García-Goñi, 2008).

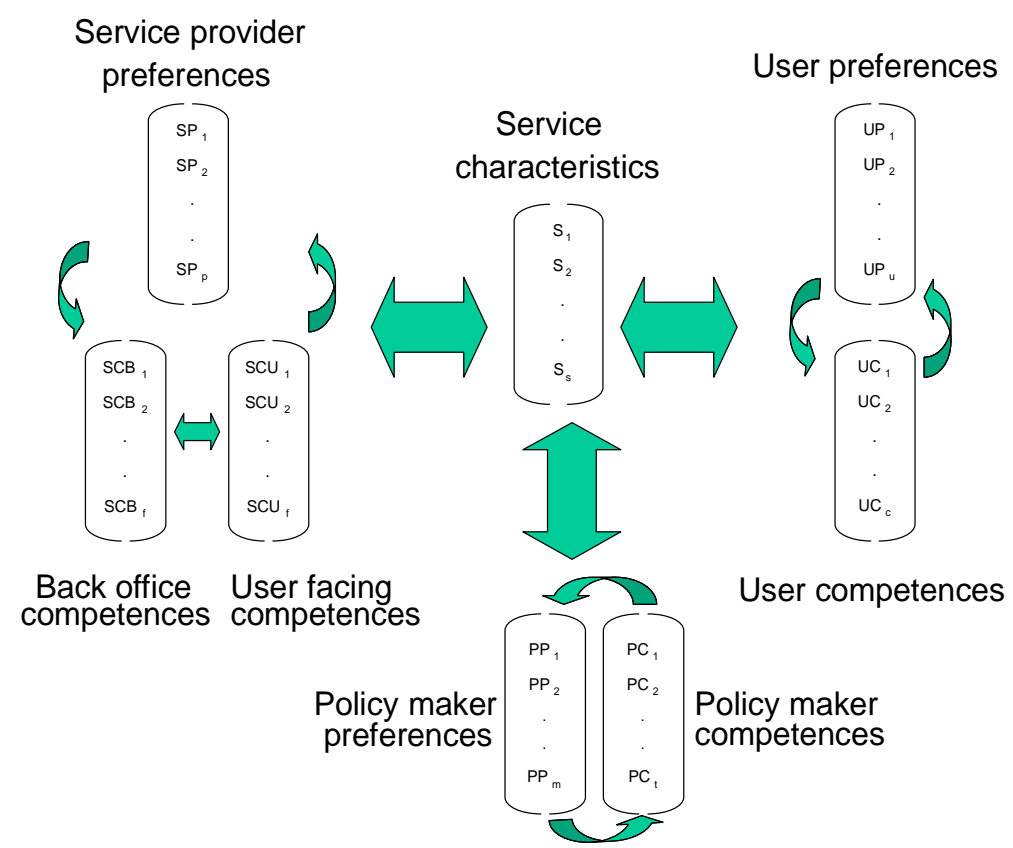

Turning to the 'process' by which social innovations are created, developed and diffused across a society, the multi-agent model helps us to examine a number of issues concerning user participation and the related issue of citizen empowerment.

Rather than being an independent entity, a new service-based social innovation is the medium through which multiple agents communicate their preferences and competences (Figure 1). One cannot understand the emergence and use of a social innovation without an explicit examination of the way in which the interests/preferences of different agents interact. It is this interaction which determines the direction and rate of change of the service characteristics that make up a social innovation.

The co-creation of a social innovation focuses attention on areas of common interest between different stakeholders, and/or the coalescing interests that are necessary for the co-creation of a social innovation. This occurs because as indicated by the arrows in Figure 1, the preferences and competences of each type of agent (provider, end user, policy-maker) are in part privately determined but also partly socially influenced by the preferences and competences of the other agents who make up the innovation environment. For example, community micro-finance extends the opportunities for citizens to set up their own businesses, build new homes etc. This has positive economic and social impact on a community, with positive externalities for both new and existing businesses, raising local output and income, and the tax base for improvements in public service provision (e.g. schools, roads, and community sanitation).

The development and diffusion of social innovations requires both (a) the direct implementation of knowledge and competences of citizens and organizations (public, private or the third sector), and (b) the mobilization of material and/or immaterial factors. Interactions between key stakeholders facilitate/inhibit the co-creation of social innovations, shape the 
features and characteristics of innovations, and determine the extent to which the resulting innovations diffuse.

The preferences and competences of agents determine the nature and the success of social innovation. In turn, the widespread diffusion of a social innovation alters the preferences and competences of agents. In other words, there is a long-term co-evolution between agents' competences and interests, and social innovations. The nature of radical social innovations is such that their diffusion alters the status quo in a society. A social innovation alters agents' mental models regarding the range of options that are socially feasible and the ways in which services can be co-created and delivered. This captures the central neo-Schumpeterian message of long-run change. A system does not simply grow over time, its composition qualitatively changes due to the introduction of social innovations that support previously unavailable services and activities.

As previously noted, scholars such as Lallemand (2001) highlight the active role played by citizens within social innovations. The inventor may be a citizen, initially motivated to develop a new service which addresses their own needs. An interesting issue raised by the Windrum, Schartinger and Waring paper in this special issue is the attitude towards intellectual property of social innovators. Rather than seeking to protect their intellectual property, or earn rents from formal IPR (patents or copyright), social innovators are keen for novel ideas to be taken up quickly by others, and for them to spread widely across society.

Citizens could be involved in co-creating, trialling, or else implementing and delivering social innovations. For example, German teams organising camps for Syrian refugees ask refugees for ideas on how to improve conditions. It is important to note that social innovation is not antithetical to business - whether it be profit-making private businesses or not-for-profit organisations. An example is provided by the case study by Windrum et al. (2016) of portable AEDs in Austria. Private firms in Austria have been encouraged to set up production of portable AED devices that could be used by laypeople within minimal training. In other cases, citizens, perhaps without prior business experience, may be motivated to become a service provider. Indeed, there has been a rise in the number of new start-ups and not-for-profit ("third sector") organisations in social and health sectors in countries such as the Netherlands and the UK over the past two decades.

Citizens may also play an active role producing and delivering a service that is a social innovation. For services generally, the knowledge, experience and motivation of users can have a direct impact on the productivity of the provider. In the AED example, (Windrum et al., 2016), it is laypeople who provide emergency care to a fellow citizen who is having a heart attack. One or more citizens must search for and then apply a portable AED to the patient, while a call is made to emergency services. By actively engaging in the design and delivery of social innovations, citizens help to diffuse these innovations as "lead users" and "innovation champions" across society.

Active participation by citizens in the delivery of a service can require a particular approach to its design, organisation, and delivery. It may, as in the AED case, require changes in the law to allow laypeople to legally use the service. Another aspect to be considered is the existing competences ( $\left[U C_{1}, \ldots, U C_{c}\right]$ in Figure 2$)$ of citizens. These are necessary in order to coproduce and deliver the service (see Figure 2). The active engagement of the general public presupposes that they have both the confidence and the requisite competences to act. The AED case study (ibid) highlights that $\left[U C_{1}, \ldots, U C_{c}\right]$ are strongly affected by the first aid training 
which laypeople receive. In Austria, the Austrian Red Cross (ARC) is the primary provider of first aid training and it actively pursued a nation-wide first aid training programme, supported by national legislation which stipulated that workplace training is obligatory and that every employer must train their personnel in the use of AEDs as part of this first aid training.

\section{Figure 2. Interaction of user and producer competences for the delivery of a social innovation.}

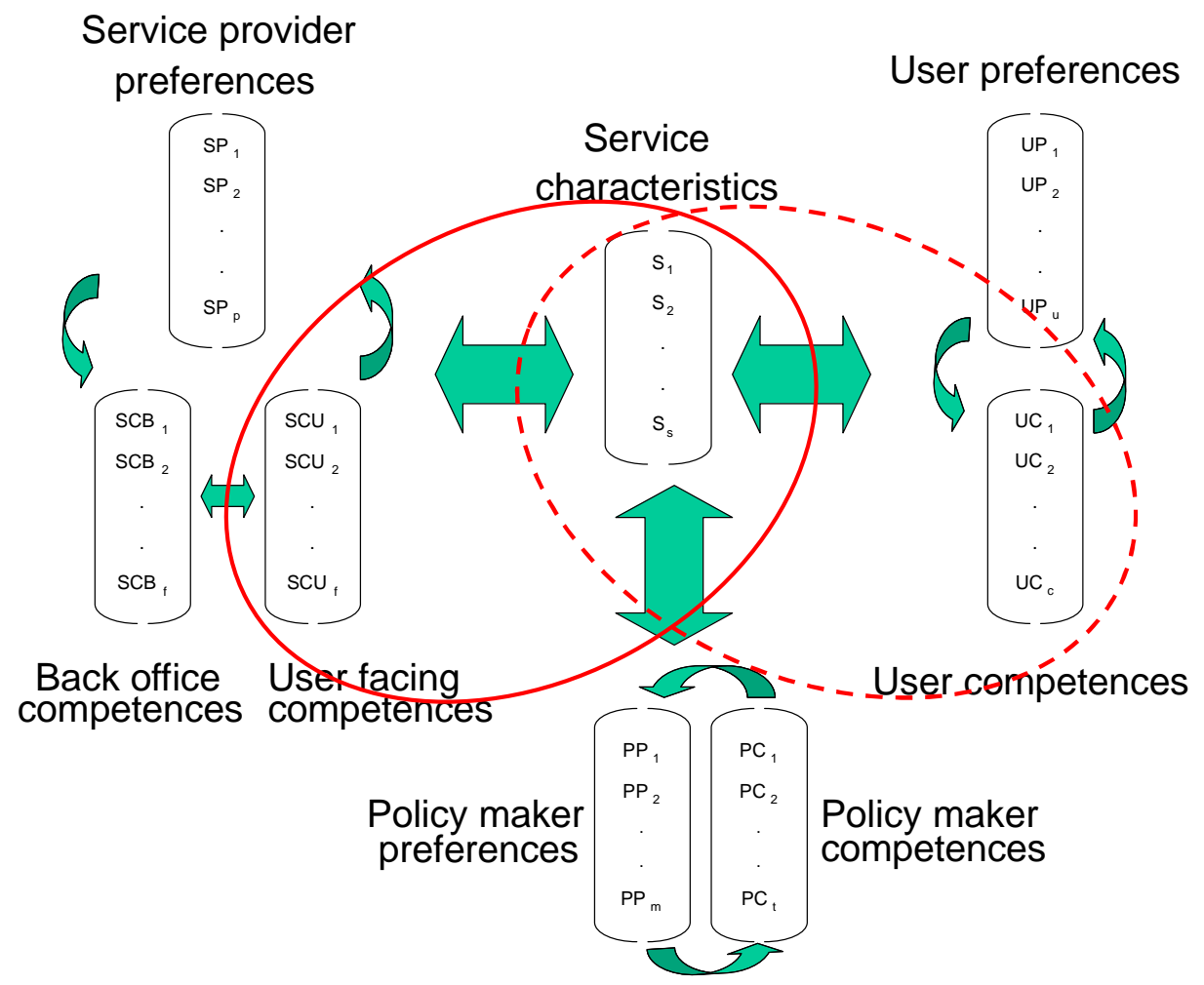

More generally, the last couple of decades have seen a move towards more "patient-centred health", particularly with respect to the management of chronic medical conditions. This encourages a shift from the traditional model in which a patent is the passive recipient of healthcare to an "empowered patient". What if the relevant competences $\left[U C_{1}, \ldots, U C_{c}\right]$ are not in place? This raises a set of important issues around how best to empower citizens, e.g. by providing the education and training needed to self-manage their conditions, and the expertise required to engage with the latest information on their condition and make informed health and medical choices. 


\section{A research agenda for service and social innovation studies}

Service innovation studies and social innovation studies can be mutually enriching on many points, which deserve to be explored (Djellal and Gallouj, 2012): the theoretical perspectives favoured, the nature of innovation and the question of its identification and measurement, its modes of organization, its appropriation regimes, the evaluation of its effects, public policies in support of innovation. These different issues are interesting avenues for a research agenda.

\section{Theoretical perspectives and the nature of innovation}

Service innovation studies and social innovation studies are in search of theoretical frameworks that would be able to account for their nature and dynamics. Taking industrial innovation as a landmark, service and social innovation studies are both part of the so-called "assimilation, demarcation, integration" framework (Gallouj, 2010). However, within this framework, they follow reverse paths that require further exploration.

Thus, in services innovation studies, the assimilation perspective (supporting the view that innovation in services is similar to innovation in manufacturing) has long been dominant. It has then given way to a demarcation perspective (focusing on differences between manufacturing and services in terms of innovation) and finally to an integration or synthesis perspective (aiming to develop unifying theoretical innovation models beyond sectoral boundaries).

In social innovation studies, the theoretical journey seems to be the reverse. It seems to have been dominated by a demarcation perspective, insofar as it is its non-technological dimension as opposed to industrial (technological) innovation that essentially defined social innovation. It is only at a later stage that certain forms of technological innovation were envisaged as vectors or modalities of social innovation, thus leaving room for an assimilation perspective.

While for service innovations studies and social innovations studies, the theoretical paths (limited here to assimilation/demarcation perspectives) are the opposite, the end result is the recognition and reconciliation of the two facets of innovation: technological (assimilation) and non-technological (demarcation).

\section{The measurement issue}

While, from the theoretical viewpoint, some dimensions of the innovation gap in service innovation studies and to a lesser extent in social innovation studies have been filled, others remain or are emerging. However, from the methodological viewpoint, unlike service innovation, no explicit effort has been made by OECD to include social innovation into its official innovation indicators (Oslo Manual). Thus, whether at the scientific or institutional level (OECD manuals), the measurement challenge is far from over and it must remain a priority in our research agendas.

Social innovation and service innovation alike are difficult to fit in the rigid categories of standard innovation questionnaires based on official indicators. There are at least four reasons for such a difficulty. The first reason is the very wide range of possible forms of innovation: a product, a service, a process, an organization, a principle, a regulation, an institution... The second reason is that these innovations are generally combinatorial. They involve complex packages, new concepts, new formulas (in trade, hotels, restaurants, for example...). The third 
reason is the emergent and non-programmed nature of certain innovations: ad hoc innovations, bricolage innovations, tailor-made innovations... The fourth reason is the nature of the institutional units that are at the origin of these innovations. Indeed, beyond firms, these institutional units also include analytical categories that survey may have some difficulties to catch: citizens or heterogeneous groups mobilizing multiple and varied actors (see next section).

These new measurement challenges are often closely linked to major societal challenges that social innovation studies and service innovation studies should address together. These include service innovation challenges related to ecological issues, developing and emerging countries, population ageing and the gender issue.

\section{Organizational and structural issues}

Service innovation studies and social innovation studies raise a number of important organizational and structural issues that must be at the forefront of a research agenda. These issues include addressing service innovation and social innovation from different (not necessarily independent) angles: the internal organization of innovation processes, entrepreneurship, employment and qualifications, network and system dynamics at different levels...

\section{The internal organization of innovation processes}

The participation of the client or the user plays a central role in both service innovation and social innovation. The very nature of social innovation is sometimes described by this coproduction, which amounts to identifying the nature of innovation with its mode of organization. Although the recognition of the role of the customer in service production, service and social innovation is old and well documented, new avenues for research are open, in particular by new technologies that make it possible to consider new roles for customers in the co-creation of service and social innovation. In service innovations studies, but also to a lesser extent in social innovation studies, some material artefacts and some new services can be developed "in the laboratory" following a "stage-gate" linear process within the "New Service Development" framework. However, in both service and social innovation studies, what dominate is openness and interaction, and also informal and non-programmed dimensions.

\section{Entrepreneurship}

Scientific work on entrepreneurship in its relationship with service innovation and social innovation lags behind, resulting in a research gap which needs to be bridged. Again, service innovation and social innovation can find a common ground of play in a number of societal issues: environmental issues (source of a form of entrepreneurship that can be labelled ecological entrepreneurship), gender issues (and female entrepreneurship), ageing (and what might be called "silver" entrepreneurship, meaning an entrepreneurship seeking to meet seniors needs in terms of new products and new services), etc.

\section{Employment and skills}

One of the main myths about the post-industrial society is that it would be a "society of servants", creating "low-skill jobs", sometimes called "Mac jobs" (Gallouj, 2002). This myth about services and service innovation also holds for social innovation. In order to overcome these myths, a forward-looking analysis of how service innovation and social innovation is likely to change the job spectrum is a research and public policy priority. 


\section{Smart Service Ecosystems}

The advent of smart service systems (SSS) is the latest step in the process of endogenising technologies in services. SSS combine smart technologies, individuals (customers, producers, citizens...), organizations that interact to exchange resources and co-create value. These SSS are an important research issue, and again, a common ground for social innovation studies and service innovation studies. Thus, for example, social media platforms like Twitter, Facebook, and LinkedIn are SSS. These highly developing social networks interact with economic networks that can rely on them to co-produce service and social innovation (Uratnik, 2016). This interconnection between social and economic networks (the blurring of boundaries between them) is a research subject that needs further development.

\section{Innovation networks and systems}

A research priority that began to emerge some time ago but which deserves special attention is the question of innovation networks and systems in which service organizations occupy a central place (not restricted to a support agent function) and in which the production of nontechnological forms innovations could take its rightful place. In a way, it is a question of tertiarizing the concepts of innovation systems and networks. Thus, the new institutional arrangements that we have called Public Private Innovation Networks in Services (Gallouj et al., 2013) are multi-agent systems that reflect how heterogeneous actors (public, private and third sector) interact to co-produce, in various configurations, not only technological innovations but also social or service innovations.

\section{The appropriation issue}

In service innovation studies, the debate on the appropriation of innovation focuses not on the legitimacy of protection, but on its technical modalities that do not conform to traditional mechanisms such as patents. In social innovation studies, the protection issue is rarely raised or is not considered as legitimate. Indeed, the success of a social innovation is measured by its diffusion rate beyond its promoters, in other words by its rate of imitation. Nevertheless, this conclusion can be qualified in a number of ways. First, it is more difficult to apply when considering material artefacts. Second, since ownership philosophies differ from one stakeholder to another, ownership can be a source of conflict when social innovation is based on hybrid networks involving actors from different origins (public, private, civil society).

\section{Performance measurement issues}

In order to evaluate the performance of organizations, based on the theory of conventions (Boltanski and Thévenot, 1991), service research has developed a multicriteria evaluation framework that can be applied to the effects of social innovation (Gadrey, 1996; Djellal and Gallouj, 2008). This framework distinguishes five performance concepts, which correspond to different "worlds" that focus on different facets of production: the industrial and technical world (which defines performance in terms of volumes and traffics), the commercial and financial world (which address performance through monetary and financial operations), the domestic world (which links performance to the quantity and quality of interpersonal links), the social-civic world (and performance in terms of equality, equity, fairness), the reputation world (which reflects performance in terms of brand image). The performance of an organization or a nation can be assessed according to these different registers, which may be complementary or competing.

\section{Public policy issues}


Advances in public policies for innovation in services have naturally followed the same path as theoretical perspectives, ranging from assimilation to demarcation and then integration (Rubalcaba, 2006). It should be noted that these advances too often express theoretical awareness more than concrete political achievements. If there is a policy gap with respect to service innovation, this gap is even more pronounced with regard to social innovation. Thus, addressing public policies for social innovation and focusing on social innovation in public services as a part of these policies are important research priorities.

Overall, a better mutual understanding of social innovation and service innovation in light of each other is expected to further reduce the hidden or invisible innovation gap in our economies, and to allow a shift towards a new comprehensive innovation paradigm.

\section{The contribution of the three papers selected for this special issue}

After the introduction, the second section of this special issue describes a case study carried out by Paul Windrum, Doris Schartinger and Justin Waring. The study examines the development and diffusion of therapeutic patient education (TPE) for Type 2 diabetes in Austria. Patient education is an example of the ongoing trend towards patient-centred healthcare, which alters the relationship between medical practitioners and patients, empowering the patient's selfcare and giving the practitioner the role of a facilitator. This development includes an institutional change that requires institutional work to materialize. The institutional work concerns, not only the creation of new institutions, but also the purposive disruption of old ones (deinstitutionalization). A research gap that the study aims to narrow is the link between different types of disruption and creation work.

After reviewing several characterisations of the concept of social innovation, the authors focus on the idea that these innovations are 'social' in both their ends and their means (BEPA, 2010). With a longitudinal empirical analysis, they aim to show that TPE is a radical social innovation within medicine, more specifically in chronic healthcare management. The results indicate that professional associations have an important role in the field-level institutional work. The results also highlight an interplay between various national professional associations, university hospitals and key policy organisations. The knowledge provided on the role of professional associations in institutional work is valuable because this topic that has not been addressed in earlier research. In more general terms, the paper contributes to the analysis of the relationship between institutional change and the development of social innovations.

In the third section, Maureen McKelvey and Olof Zaring examine the roles of universities in the delivery of social innovations. They build on the literature of innovation economics and evolutionary economics and start from the argument that social innovation should be a public good. They examine the relationship between services and social innovations and identify social innovation as the co-delivery of services through the involvement of producers together with users and stakeholders. In addition, they specify three criteria to decide whether a service is a social innovation: it must include social change, welfare improvement, and system change. A conceptual model summarises these characteristics and criteria.

The model also serves the empirical analysis of the role of universities in the production of social innovations. This analysis focuses on the issue of how and why the university can be an 
intermediary that is directly involved in creating the co-delivery of social innovations through knowledge-intensive services: education, research and societal interaction. The empirical analysis has been carried out via a case study in Sweden. The paper narrows the research gap that exists in previous literature regarding the role of universities: their business-related activities and the university-industry interaction have been highlighted, whereas the promotion of social innovation and the engagement of universities with society have been neglected. Another contribution is the development of the idea of how the literature on service innovation could be used more extensively to understand the activities of universities.

The fourth section, authored by Paola Garrone, Angelamaria Groppi and Paolo Nardi, includes an empirical analysis of social innovations that enhance urban liveability in large cities. The authors state that urban studies are a central strand in the field of social innovation as many social problems concentrate in cities. The paper presents case studies in 19 Italian cities and focuses on the role of third sector organizations that earlier research has shown to trigger new networks promoting social innovations. The focus is on infrastructure services (mobility, housing etc.) that are particularly critical for urban liveability but have been underrepresented in social innovation research. The definition used for social innovation highlights solutions to social problems and the satisfaction of unanswered human needs through the change of social relations and empowerment of citizens (Moulaert, 2005; van der Have and Rubalcaba, 2016).

Starting from the general argument that social innovation frequently materializes through the offer of new services, the study examined the social and organizational mechanisms adopted in the provision of new services. It also examined the city liveability dimensions that are most influenced by social innovations. In the sample, the most pervasive development mechanisms were flexibility in service provision and the progressive enlargement of service mix. In many cases, a diverse base of users and the involvement of volunteers were also important. Enhanced accessibility and equity turned out to be the most important dimensions of liveability of cities: formerly marginalized groups of citizens achieved access to services. Participation and sustainability, which have been identified as other liveability dimensions, were less prominent in this study. The study contributes to earlier research by opening up the process of social innovation in the topical contexts of urbanization and infrastructure services. Other contributions are 'testing' the framework of the impact dimensions of social innovation (Timmer and Seymoar, 2005) and studying the role of the third sector organizations.

\section{Concluding remarks}

This initial paper has focused on the relationships between service innovation and social innovation, arguing that the earlier research into social innovation has not paid enough attention to service aspects. However, several studies have revealed that the outcomes of social innovation are often services. In addition, service innovations are becoming increasingly social: co-creation and user empowerment are central processes in these innovations. A common ground for the studies on service innovation and social innovation is justified by the fact that there are major societal challenges that these studies should address together. Also the nature of innovation processes highlights similar research targets: multi-actor collaboration and "bottom-up" emphasis in defining, developing, and implementing of new innovative solutions.

In this opening article, we have started to answer the above-mentioned need for closer linkages between service innovation and social innovation studies. We have explored to move of service innovation into more social characteristics (more social goals, more social means, more multi- 
agent provision, and more social roles) and presented a taxonomy to place social innovation in service innovation modes. We also propose that a multi-agent model originally developed in the service context (Windrum and García Goñi, 2008) can be applied as a model of social innovation, too. It presents the co-creation of innovation as an interaction of competences and interests of multiple providers, users (citizens), and policy makers (Windrum et al., 2016). We also present a research agenda for social innovation. It includes issues of theory, measurement, organisation, appropriation, performance measurement, and public policy. In several points, we suggest comparison with service innovation studies. For instance, we ask whether the relationship between technological and service emphasis, which in service innovation studies has developed from assimilation to demarcation, follows a reverse path in social innovation studies. We also suggest that the importance of public-private innovation networks in which service organisations play a central role (ServPPINs) means tertiarizing the concepts of innovation systems.

The three other papers included in this special issue illustrate in more detail the different perspectives on the definition of social innovation, highlighting both means and ends: empowerment of citizens, solutions to social problems, and services and systems as outcomes of social innovation. They examine social innovations at both the societal and organisational levels. They also provide examples of social innovations in various contexts: healthcare, education and infrastructure development. Finally, they create new theoretical linkages by specifying how service innovation research could be utilised in the context of social innovation and how the research streams of institutional change and urban studies could be combined with social innovation research.

Social innovation is directly linked to policy contexts. There are three broad areas of policy intervention for growth and welfare contribution that seem to be especially appropriate for social innovation: strengthening service-specific innovation and innovation capabilities; facilitating cooperation and networks involving service firms; and empowering the public sector and the "third sector" with respect to cooperation (Wazenbock et al., 2013). Based on our analyses in this special issue, these could be supplemented and redrafted as follows: understanding and leveraging social goals and social means in innovation policies; strengthening social innovation capabilities; empowering users, communities and citizens for co-production and co-innovation; facilitating cooperation and networks between private, public and third sector; and promoting the scalability of success stories. 


\section{References}

- Albury, D. 2005. "Fostering innovation in public services". Public money and management, 25(1), 51-56.

- BEPA / Hubert, A. 2010, Empowering people, driving change: Social innovation in the European Union. Accessed in 1 July 2017. http://ec.europa.eu/bepa/pdf/publications_pdf/social_innovation.pdf

- Boltanski L. and L. Thévenot. 1991. De la Justification. Les économies de la grandeur, Paris : Gallimard.

- Bouchard C. 1999. Recherche en sciences humaines et sociales et innovations sociales, Contribution à une politique de l'immatériel, Conseil québécois de la recherche sociale (CQRS). Québec: les Publications du Québec.

- Chesbrough, H. 2011. Open Services Innovation: Rethinking Your Business to Grow and Compete in a New Era. New York: John Wiley \& Sons.

- Djellal, F., and F. Gallouj. 2008. Measuring and improving productivity in services: issues, strategies and challenges, Cheltenham and Northampton: Edward Elgar Publishers.

- Djellal, F., and F. Gallouj. 2012. "Social innovation and service innovation", in Challenge Social Innovation Potentials for Business, Social Entrepreneurship, Welfare and Civil Society edited by F. H-W. Hochgerner, and J. Howaldt, 119-137. Berlin: Springer.

- Djellal F., Gallouj F., and I. Miles. 2013. "Two decades of research on innovation in services: Which place for public services?" Structural Change and Economic Dynamics, $27,98-117$

- Gadrey J. 1996. Services: la productivité en question, Paris: Desclée de Brouwer

- Gallouj F. 2002. "Innovation in services and the attendant old and new myths", Journal of socio-economics, 31(2), 137-154.

- Gallouj F. 2010. "Services innovation: assimilation, differentiation, inversion and integration", chapter 75 in The Handbook of Technology Management edited by H. Bidgoli, 989-1000, John Wiley and Sons, Hoboken, New Jersey.

- Gallouj F. 2002. Innovation in the service economy: the new wealth of nations. Cheltenham and Northampton: Edward Elgar Publishing.

- Gallouj, F., and F. Djellal, eds. 2010. The handbook of innovation and services: a multidisciplinary perspective. Cheltenham and Northampton: Edward Elgar Publishing.

- Gallouj, F., and O. Weinstein. 1997. "Innovation in services". Research policy, 26(4), 537556.

- Gallouj, F., L. Rubalcaba, and P. Windrum, eds. 2013. Public-Private Innovation Networks in Services: the dynamics of cooperation in service innovation. Cheltenham and Northampton: Edward Elgar Publishers.

- Gershuny J. 1978. After industrial society? the emerging self-service economy, Mac Millan.

- Gershuny J., and Miles I. 1983. The new service economy: the transformation of employment in industrial societies, Frances Pinter.

- Harrison, D., J-L Klein, and P.L. Browne. 2010. "Social innovation, social enterprise and services", in: The Handbook of Innovation and Services, edited by F. Gallouj, and F. Djellal, Cheltenham and Northampton: Edward Elgar.

- Hipp, C. 1999. "Knowledge-intensive business services in the new mode of knowledge production". AI \& Society, 13(1-2), 88-106.

- Hochgerner, J. 2013. "Social innovations and the advancement of the general concept of innovation". Chapter 12 in Social Innovation: New Forms of Organisation in KnowledgeBased Societies, 12, edited by C. Ruiz, and C. Parra. New York: Routledge. 
- Howaldt J., and M. Schwarz. 2010. Social Innovation: Concepts, research fields and international trends, Sozialforschungsstelle Dortmund ZWE der TU-Dortmund.

- Lallemand D. 2001. Les défis de l'innovation sociale, Issy-les-Moulineaux, ESF Editeur.

- Lancaster, K.J. 1966. "A New Approach to Consumer Theory." The Journal of Political Economy 74(2): 132-157.

- Mbiti, I., and D. N. Weil. 2011. "Mobile banking: the impact of M-PESA in Kenya", NBER Working Paper 17129, National Bureau of Economic Research.

- Miles, I. 2005. Knowledge intensive business services: prospects and policies. Foresight, 7(6), 39-63.

- Moulaert, F. et al., eds. 2013. The international handbook on social innovation: collective action, social learning and transdisciplinary research. Cheltenham and Northampton: Edward Elgar Publishing.

- OECD LEED Forum on Social Innovations. 2000. Accessed 1 July 2017. http://www.oecd.org/cfe/leed/forum/socialinnovations

- Osborne, S. P. 2013. Voluntary organizations and innovation in public services. Routledge.

- Osborne, S. P., and L. Brown, L., eds. 2013. Handbook of innovation in public services. Edward Elgar Publishing.

- Osborne, S. P., Radnor, Z., \& Strokosch, K. 2016. "Co-Production and the Co-Creation of Value in Public Services: A suitable case for treatment?" Public Management Review, 18(5), 639-653.

- Pol, E., \& Ville, S. 2009. "Social innovation: Buzz word or enduring term?" The Journal of Socio-Economics, 38(6), 878-885.

- Reinstaller, A. 2013. An evolutionary view on social innovation and the process of economic change (No. 43). WWWforEurope.

- Rubalcaba, L. 2006. "Which Policy for Innovation in Services?", Science and Public Policy, 33 (10), 745-56.

- Rubalcaba, L. 2016. "Social Innovation and its Relationships with Service and System Innovations." In Service Innovation. Novel Ways of Creating Value in Actor Systems, edited by M. Toivonen, 69-93. Berlin, Springer.

- Rubalcaba, L., S., Michel, J., Sundbo, S.W., Brown, and J. Reynoso. 2012 "Shaping, organizing, and rethinking service innovation: a multidimensional framework", Journal of Service Management, Vol. 23 Iss 5, pp. 696 - 715.

- Smith A. 1776. An inquiry into the wealth of nations. London: Strahan and Cadell.

- Strambach, S. 2008. "Knowledge-Intensive Business Services (KIBS) as drivers of multilevel knowledge dynamics". International journal of services technology and management, 10(2-4), 152-174.

- Sundbo, J., and M. Toivonen. 2011. "Introduction", in User-based innovation in services edited by J. Sundbo and M. Toivonen M., eds., Cheltenham and Northampton: Edward Elgar.

- TEPSIE. 2013. Theoretical, Empirical and Policy Foundations for Social Innovation in Europe (TEPSIE) http://www.tepsie.eu/

- Tether, B. 2005. "Do Services Innovate (Differently)? Insights from the European, Innobarometer Survey". Industry and Innovation 12(2), 153-84.

- Timmer, V., N. K. Seymoar, 2005. "The Livable City: World Urban Forum 2006”, Vancouver Working Group Discussion Paper. Western Economic Diversification Canada.

- Uratnik, M. 2016. "Interactional service innovation with social media users", Service Science, 8(3), p. 300-319.

- van der Have, R. P., and L. Rubalcaba. 2016. "Social innovation research: An emerging area of innovation studies?" Research Policy, 45(9), 1923-1935. 
- Wanzenböck, I., L. Rubalcaba, O. Montes, and M. Weber. 2013. "Policy Developments and Measures for Enhancing ServPPINs Dynamics." In Public Private Innovation Networks in Service, edited by F. Gallouj, L. Rubalcaba, and P. Windrum, 432-461. UK: Edward Elgar.

- Windrum P., and García-Goñi M. 2008. "A neo-Schumpeterian model of health services innovation”. Research Policy, 37 (4), 649-672.

- Windrum, P. and P. Koch, eds. 2008. Innovation in Public Sector Services Entrepreneurship, Creativity and Management, Cheltenham and Northampton: Edward Elgar.

- Windrum, P. 2013. "Multi- agent framework for understanding the success and failure of ServPPINs" in Public-Private Sector Innovation Networks, edited by F. Gallouj, L. Rubalcaba, and P. Windrum, 88-103. Cheltenham: Edward Elgar.

- Windrum, P., D. Schartinger, L. Rubalcaba, F. Gallouj, and M. Toivonen. 2016. "The CoCreation of Multi-Agent Social Innovations: A Bridge Between Service and Social Innovation Research.” European Journal of Innovation Management, 19 (2): 150-166. 